\title{
Penggunaan Metode Diskusi Sebagai Upaya Meningkatkan Hasil Belajar Bahasa Indonesia Peserta Didik di Kelas I SDN 58/X Teluk Majelis Semester Ganjil Tahun Ajaran 2021/2022
}

\author{
Rosianty \\ SDN 58/X Teluk Majelis \\ Desa Teluk Majelis, Teluk Majelis, Kec. Kuala Jambi, Kab. Tanjung Jabung Timur Prov. Jambi \\ rosianty3091@gmail.com
}

\begin{abstract}
This study aims to describe and obtain information on improving Indonesian language learning outcomes through the discussion method. This research is a classroom action research consisting of two cycles, each cycle consisting of two meetings. Each meeting consists of four stages, namely planning, implementation, observation and reflection. The subjects of this study were the first grade students of SDN 58/X Teluk Majelis, totaling 21 people. This research was conducted in the odd semester of the 2021/2022 academic year. Data collection techniques using tests, observations, and documentation. Data were analyzed using percentages. The results of the study indicate that the discussion method can improve the learning outcomes of first grade Indonesian students at SDN 58/X Teluk Majelis by giving rewards.
\end{abstract}

Keywords: Indonesian Language Learning Outcomes, Discussion

\begin{abstract}
Abstrak
Penelitian ini bertujuan untuk mendeskripsikan dan mendapatkan informasi peningkatan hasil belajar Bahasa Indonesia melalui metode diskusi.Penelitian ini merupakan penelitian tindakan kelas yang terdiri dari dua siklus masing-masing siklus terdiri dari dua kali pertemuan. Masing-masing petemuan terdiri dari empat tahapan yaitu perencanaan, pelaksanaan, observasi dan refleksi. Subjek penelitian ini adalah peserta didik kelas I SDN 58/X Teluk Majelis yang berjumlah sebanyak 21 orang. Penelitian ini dilaksanakan pada semseter ganjil tahun ajaran 2021/2022. Teknik pengumpulan data menggunakan tes, observasi, dan dokumentasi. Data dianalisis menggunakan persentase. Hasil penelitian menunjukkan bahwa melalui metode diskusi dapat meningkatkan hasil belajar Bahasa Indonesia peserta didik kelas I SDN 58/X Teluk Majelis dengan tindakan pemberian reward/hadiah.
\end{abstract}

Kata kunci: Hasil Belajar Bahasa Indonesia, Diskusi

Copyright (c) 2022 Rosianty

Corresponding author: Rosianty

Email Address: rosianty3091@gmail.com (Desa Teluk Majelis, Kab. Tanjung Jabung Timur, Jambi)

Received 01 December 2021, Accepted 20 January 2022, Published 28 January 2022

\section{PENDAHULUAN}

Pendidikan merupakan usaha untuk membina mengembangkan potensi sumber daya manusia melalui berbagai kegiatan belajar mengajar yang diselenggarakan pada berbagai tingkat pendidikan dari pendidikan dasar, pendidikan menengah, dan perguruan tinggi. Pendidikan juga merupakan suatu usaha yang dilakukan dengan sengaja dan terencana dengan maksud untuk mengubah tingkah laku ke arah yang lebih baik. Pendidikan diharapkan dapat memegang peranan penting terhadap kemajuan suatu negara dan bangsa. Hal ini disebabkan karena pendidikan merupakan suatu upaya untuk meningkatkan kualitas setiap individu baik secara langsung maupun tidak langsung dan mengikuti laju perkembangan ilmu pengetahuan dan teknologi dalam rangka menyukseskan pembangunan yang sejalan dengan kebutuhan manusia.

Setiap warga negara berhak mendapatkan pendidikan (UUD 1945 Pasal 31 Ayat 1). Menurut UU Sisdiknas No. 20 Tahun 2003 Pasal 1 Ayat 1, Pendidikan adalah usaha sadar terencana untuk 
mewujudkan suasana belajar dan proses pembelajaran agar peserta didik secara aktif mengembangkan potensi dirinya untuk memiliki kekuatan spritual keagamaan, pengendalian diri, kepribadian, kecerdasan, akhlak mulia, serta keterampilan yang diperlukan dirinya, masyarakat, bangsa dan negara. Pendidikan di sekolah harus mampu mengubah peserta didik menjadi seorang yang berpendidikan dan terampil. Salah satu masalah pokok dalam pembelajaran pada pendidikan formal dewasa ini adalah rendahnya daya serap peserta didik terhadap pelajaran. Hal ini terlihat dari hasil belajar peserta didik yang rendah dalam mengerjakan soal baik dalam ulangan harian, ulangan semester maupun ujian akhir sekolah. Pendidikan disekolah merupakan tanggung jawab guru. Dalam arti bahwa dalam setiap guru terletak tanggung dan keprofesionalan untuk menyukseskan tujuan pendidikan yang telah ditetapkan.

Guru sebagai pendidik yang berhubungan langsung dengan anak didik harus ikut serta dan bertanggung jawab dalam meningkatkan hasil belajar anak didik. Salah satu upaya yang dapat dilakukan pendidik adalah memiliki keterampilan mengajar dan menguasai model-model pembelajaran. Hal ini akan dapat memotivasi peserta didik untuk lebih aktif dalam belajar sehingga tercipta hubungan timbal balik yang baik antara peserta didik dan guru.

Idealnya pendidikan akan melahirkan peserta didik yang berkarakter, bermoral, berpengetahuan dan kemampuan dasar lainnya untuk dijalankan dalam kehidupan bermasyarakat, berbangsa, dan bernegara. Peserta didik harus aktif dan terlibat langsung dalam kegiatan pembelajaran agar kegiatan belajar menjadi bermakna bagi peserta didik, sehingga peserta didik mendapatkan pengalaman belajar yang interaktif, inspiratif, memotivasi, dan tidak menjemukan.

Bahasa merupakan aspek penting dalam perkembangan intelektual, sosial, dan emosional peserta didik. Di samping itu, bahasa juga merupakan penunjang keberhasilan dalam mempelajari semua bidang studi. Pada dasarnya belajar bahasa adalah belajar berkomunikasi. Oleh karena itu, dalam pembelajaran Bahasa Indonesia diarahkan untuk meningkatkan kemampuan peserta didik dalam berkomunikasi dengan menggunakan bahasa indonesia yang baik dan benar, baik secara lisan maupun tertulis (Depdiknas, 2006:65).

Pembelajaran Bahasa Indonesia meliputi aspek menyimak, berbicara, membaca, dan menulis. Menulis merupakan suatu keterampilan penting dalam kehidupankarena setiap kegiatan di masyarakat atau di sekolah tidak lepas dari kegiatan menulis. Disamping itu, keterampilan menulis merupakan salah satu kompetensi yang harus dimiliki oleh seseorang sekaligus menjadi salah satu tujuan pendidikan dasar Depdiknas (2006:317) yaitu agar peserta didik memiliki kemampuan berkomunikasi secara efektif dan efisien sesuai dengan etika yang berlaku, baik secara lisan maupun tulis. Menulis adalah sebuah kegiatan menuangkan pikiran, gagasan, dan perasaan seseorang melalui sebuah coretan pena pada kertas yang isinya memiliki makna atau maksud tertentu.

Fenomena yang ditemukan penulis dalam observasi di kelas I SDN 58/X Teluk Majelis adalah rendahnya hasil belajar peserta didik yang dapat dilihat dari bukti fisik berupa hasil ulangan 
harian peserta didik dan proses kegiatan pembelajaran di kelas. Kegiatan pembelajaran yang dilakukan menggunakan metode ceramah yang lebih berpusat pada guru (teacher center) sehingga peserta didik menjadi pasif, tidak kreatif, dan tidak mandiri dalam belajar karena peran guru lebih menonjol dalam kegiatan pembelajaran, sementara peserta didik hanya menunggu materi dari guru.

Data yang diperoleh dari hasil belajar ulangan harian ganjil 2020/2021 menunjukkan hasil ujian rata-rata peserta didik di bawah KKM yang ditetapkan 63, atau dari 21 orang peserta didik, hanya 25 orang yang mampu mencapai batas ketuntasan yang ditetapkan. Suatu metode dipandang tepat untuk suatu situasi dapat dirasa kurang tepat untuk situasi yang lain. Pembelajaran sering dilakukan dengan menggunakan berbagai metode secara bervariasi, sehingga tidak terasa monoton dan membosankan. Akan tetapi suatu metode penggunaanya biasa berdiri sendiri, tergantung pada pertimbangan berdasarkan situasi pembelajaran yang relevan.

Pasaribu (1986: 86) berpendapat bahwa metode diskusi adalah cara penyampaian informasi dan pengetahuan kepada peserta didik secara lisan atau tertulis. Dengan kata lain, metode diskusi adalah suatu cara penyajian bahan dengan cara guru memberi penjelasan dua pihak atau lebih untuk mencapai tujuan pengajaran. Dari pendapat di atas dapat disimpulkan bahwa metode diskusi adalah suatu penyampaian atau penyajian materi pelajaran dari guru kepada peserta didik yangdilakukan secara lisan di dalam proses belajar mengajar demi tercapainya tujuan pengajaran melalui cara penyampaian informasi atau materi pelajaran yang selain dilakukan secara lisan, juga divariasikan atau dikombinasikan penggunaannya dengan cara penyampaian lain, seperti ; Tanya jawab, pemberian tugas, dan sebagainya.

Belajar adalah modifikasi atau mempengaruhi kelakuan melalui pengalaman. (learning is defined as the modification or strengthening of behavior through experiencing). Menurut pengertian ini, belajar adalah merupakan suatu proses, suatu kegiatan dan bukan suatu hal hasil atau tujuan. Belajar bukan hanya mengingat, akan tetapi lebih luas daripada itu, yakni mengalami. Hasil belajar bukan suatu penguasaan hasil latihan, melainkan perubahan kelakuan.Pengertian ini sangat berbeda dengan pengertian lain tentag belajar, yang menyatakan bahwa belajar adalah memperoleh pengetahuan, belajar adalah latihan-latihan pembentukan kebiasaan secara otomatis, dan seterusnya (Hamalik, 2012).

Menurut Hariyanto (2012 : 19) Belajar adalah suatu aktivitas atau suatu proses untuk memperoleh pengatahuan, meningkatkan keterampilan memperbaiki prilaku sikap dan mengkokohkan kepribadian. Menurut Agus (2012:3) Learning is any relatively permanent change in behavior that is a result of past experience. (Belajar adalah perubahan perilaku yangbersifat permanen sebagai hasil dari pengalaman). Dari beberapa pendapat di atas dapat disimpulkan bahwa belajar adalah suatu proses untuk memperoleh perubahan perilaku yang bersifat permanen sebagai hasil dari pengalaman.

Pembelajaran menurut Gagne dalam Pribadi (2009:9) adalah serangkaian aktivitas yang sengaja diciptakan dengan maksud untuk memudahkan terjadinya proses belajar. Menurut Rusman (2012 : 134) "Pembelajaran pada hakikatnya adalah merupakan suatu proses interaksi antara guru 
dengan peserta didik, baik interaksi secara langsung seperti kegiatan tatap muka maupun secara tidak langsung, yaitu dengan menggunakan berbagai media pembelajaran.

Pembelajaran bahasa Indonesia diarahkan untuk meningkatkan kemampuan peserta didik untuk berkomunikasi dalam bahasa Indonesia dengan baik dan benar. Hal tersebut dilakukan baik secara lisan maupun tulis, serta menumbuhkan apresiasi terhadap hasil karya kesastraan manusia Indonesia. Standar kompetensi mata pelajaran bahasa Indonesia merupakan kualifikasi kemampuan minimal peserta didik yang menggambarkan penguasaan pengetahuan, keterampilan berbahasa, dan sikap positif terhadap bahasa dan sastra Indonesia. Standar kompetensi ini merupakan dasar bagi peserta didik untuk memahami dan merespon situasi lokal, regional, nasional, dan global. Ruang lingkup mata pelajaran Bahasa Indonesia mencakup komponen kemampuan berbahasa dan kemampuan bersastra yang meliputi aspek-aspek mendengarkan, berbicara, membaca, dan menulis.

Metode menurut Kamus Besar Bahasa Indonesia (1995 : 652) adalah cara yang teratur dan terpikir baik-baik untuk mencapai maksud dalam ilmu pengetahuan dsb.; cara kerja yang bersistim untuk memudahkan pelaksanaan suatu kegiatan guna mencapai tujuan yang ditentukan. Menurut Sri Anitah W. (2008 : 5.20) metode diskusi digunakan dalam rangka pembelajaran kelompok atau kerja kelompok yang didalamnya melibatkan beberapa orang peserta didik untuk menyelesaikan pekerjaan, tugas atau permasalahan. Sering pula metode ini disebut sebagai saah satu metode yang menggunakan pendekatan CBSA atau ketrampilan proses. Pembelajaran dengan menggunakan metode diskusi yang dilaksanakan secara efektif akan berdampak banyak kepada pengalaman peserta didik.

\section{METODE}

Jenis penelitian ini adalah penelitian tindakan kelas. Penelitian ini dilaksanakan di SDN 58/X Teluk Majelis pada semester ganjil, tahun ajaran 2021/2022. Subjek dalam penelitian ini adalah siswa kelas I dengan jumlah peserta didik 21 orang. Prosedur penelitian ini meliputi perencanaan, pelaksanaan, pengamatan, dan refleksi. Penelitian ini dilaksanakan dalam dua siklus, masing-masing siklus terdiri dari dua kali pertemuan. Teknik yang digunakan dalam pengumpulan data adalah observasi, tes, catatan lapangan dan dokumentasi. Data dianalisis melalui persentase dan reduksi data.

\section{HASIL DAN DISKUSI}

\section{Hasil Penelitian}

\section{Siklus I}

\section{Perencanaan}

Pada tahap ini peneliti mempersiapkan perangkat pembelajaran yang terdiri dari RPP, silabus, media pembelajaran, lembar aktivitas guru, dokumentasi dan observasi, lembar observasi aktivitas peserta didik. 


\section{Pelaksanaan}

Pelaksanaan siklus I pertemuan I pada hari Senin pada tanggal Selasa tanggal 9 Februari 2021 di kelas I pada pukul 08.05 sampai dengan 09.45 Wib dengan jumlah peserta didik 21 orang. Adapun tema pembelajaran pada pertemuan ini ialah diriku, dan sub tema yang dibahas adalah tubuhku. Prosedur penelitian sesuai dengan yang ada pada rencana pelaksanaan pembelajaran mulai dari pendahuluan, kegiatan inti dan penutup.

Pada kegiatan pendahuluan ini Guru memberikan salam dan mengajak semua peserta didik berdo'a menurut agama dan keyakinan masing-masing. Menyanyikan lagu "Indonesia Raya" bersama-sama. Kemudian peserta didik menyimak penjelasan guru tentang pentingnya sikap disiplin dan tanggung jawab yang akan dikembangkan dalam pembelajaran. Tidak lupa pula guru mengingatkan kepada peserta didik untuk selalu mematuhi protocol kesahatan seperti memakai masker agar terhindar dari virus covid 19. Setelah itu guru memberikan informasi tema yang akan dipelajari mengenai "Tubuhku".

Pada kegiatan inti ini guru membentuk peserta didik dalam 5 kelompok. Kemudian masingmasing kelompok duduk bersama anggota kelompoknya. Guru mengajak peserta didik untuk mengenal anggota tubuhnya dengan bernyanyi. Guru memulai kegiatan dengan mengajak peserta didik untuk menyanyikan lagu "Dua Mata Saya". Peserta didik menyanyikan lagu bersama-sama disertai tepukan sesuai dengan nama (eksplorasi). Setelah itu guru menunjukkan gambar bagian anggota tubuh dan meminta peserta didik mengamati gambar tersebut di buku peserta didik, lalu guru dan peserta didik bertanya jawab berkaitan dengan nama-nama anggota tubuh. Sambil menunjukkan baguan-bagian tubuh pada gambar tersebut. Setelah itu peserta didik diminta memegang anggota tubuh secara bergantian sesuai dengan aba-aba guru. Setelah selesai kegiatan peserta didik diminta maju ke depan dan menyebutkan nama-nama anggota tubuh sesuai dengan permainan/ mengkomunikasikan.

Pada kegiatan penutup ini peserta didik Bersama-sama peserta didik membuat kesimpulan/ rangkuman hasil belajar selama sehari. Bertanya jawab tentang materi yang telah dipelajari (untuk mengetahui hasil ketercapaian materi). Guru memberi kesempatan kepada peserta didik untuk menyampaikan pendapatnya tentang pembelajaran yang telah diikuti. Melakukan penilaian hasil belajar. Mengajak semua peserta didik berdo'a menurut agama dan keyakinan masing-masing (untuk mengakhiri kegiatan pembelajaran).

Pelaksanaan siklus I pertemuan II pada hari kamis pada tanggal 18 Februari 2021 di kelas I pada pukul 07.30 sampai dengan $08.40 \mathrm{Wib}$ dengan jumlah peserta didik 21 orang. Adapun materi pembelajaran pada pertemuan ini mengacu pada topik "Kegemaranku". Prosedur penelitian sesuai dengan yang ada pada rencana pelaksanaan pembelajaran mulai dari pendahuluan, kegiatan inti dan penutup.

Pada kegiatan pendahuluan ini Guru memberikan salam dan mengajak semua peserta didik berdo'a menurut agama dan keyakinan masing-masing. Menyanyikan lagu "Indonesia Raya" 
bersama-sama. Kemudian peserta didik menyimak penjelasan guru tentang pentingnya sikap disiplin dan tanggung jawab yang akan dikembangkan dalam pembelajaran. Tidak lupa pula guru mengingatkan kepada peserta didik untuk selalu mematuhi protokol kesahatan seperti memakai masker agar terhindar dari virus covid 19. Setelah itu guru memberikan informasi tema yang akan dipelajari mengenai "Kegemaranku".

Pada kegiatan inti ini peserta didik menyimak cerita tentang gerakan meliukkan tubuh yang dibacakan oleh guru. Kemudian peserta didik mengamati gambar yang menyertai teks. Peserta didik menyerap informasi yang disampaikan guru melalui teks dan gambar. Kemudian guru memberikan kesempatan kepada peserta didik untuk menanyakan hal-hal yang inin diketahui berdasarkan teks yang dibacakan dan digambar yang diamati. Peserta didik membaca puisi tentang sahabat. Guru memancing partisipasi aktif peserta didik dengan pertanyaan. Pertanyaan yang diberikan adalah apakah kamu memiliki sahabat dan bagaimana perasaanmu terhadapnya?.

Pada kegiatan penutup ini peserta didik Bersama-sama peserta didik membuat kesimpulan / rangkuman hasil belajar selama sehari. Bertanya jawab tentang materi yang telah dipelajari (untuk mengetahui hasil ketercapaian materi). Guru memberi kesempatan kepada peserta didik untuk menyampaikan pendapatnya tentang pembelajaran yang telah diikuti. Melakukan penilaian hasil belajar. Kemudian mengajak semua peserta didik berdo'a menurut agama dan keyakinan masingmasing (untuk mengakhiri kegiatan pembelajaran) yang dipimpin oleh salah satu peserta didik.

\section{Observasi}

Setelah dilaksanakan tahap pelakanaan sebanyak dua kali pertemuan guru melakukan tes untuk melihat hasil belajar Bahasa Indonesia menggunakan motode diskusi. Berdasrkan hasil observasi dapat dilihat hasil belajar Bahasa Indonesia peserta didik kelas I di SDN 58/X Teluk Majelis sebagai berikut.

Tabel 1. Rekapitulasi Hasil Tes Formatif Pada Siklus I

\begin{tabular}{|c|c|c|}
\hline No & Uraian & Hasil \\
\hline 1 & Jumlah Nilai & 1436 \\
\hline 2 & Rata-rata Nilai & 68.38 \\
\hline 3 & Peserta didik Tuntas & 8 \\
\hline 4 & Peserta didik Tidak Tuntas & 13 \\
\hline 5 & Persentase Peserta didik Tuntas & $38 \%$ \\
\hline 6 & Persentase Peserta didik Tidak Tuntas & $62 \%$ \\
\hline
\end{tabular}

Dari tabel di atas dapat dijelaskan bahwa Pada siklus I ini di peroleh rata - rata hasil belajar peserta didik yaitu 68,38 dengan presentase 67,57\% atau 8 peserta didik dari 21 Peserta Didik yang tuntas belajar. Hasil tersebut menunjukkan bahwa pada siklus I secara klasikal peserta didik belum tuntas belajar, karena hanya 8 peserta didik yang memperoleh nilai $\geq 70$ atau hanya sebesar $38 \%$ yang mencapai kriteria ketuntasan minimum (KKM). Sehingga, masih terdapat 13 dari 21 Peserta Didik 
yang belum tuntas belajar atau sebanyak $62 \%$. Hasil tersebut lebih kecil dari presentase ketuntasan klasikal dalam proses pembelajaran Bahasa Indonesia yang dikehendaki sebesar $80 \%$.

\section{Refleksi}

Tahap refleksi dilaksanakan pada hari Senin pada tanggal 22 Februari 2021 di kelas I pada pukul 12.00 sampai dengan 12.30 Wib yang dibantu Saprizal, S.Pd. SD. Evaluasi dilakukan bahwa guru kurang membimbing kelompok diskusi, beberapa kelompok tidak aktif dalam diskusi mungkin belum terbiasa untuk berdiskusi. Selain itu juga ditemukan bahwa guru kurang mempersiapkan diri dengan alat-alat/ media dalam rangka melengkapi bahan yang dibutuhkan seperti laptop,infokus, buku sumber dan lainnya. Guru harus mampu membimbing peserta didik dalam diskusi kelompok, dan harus mendatangi semua kelompok tanpa membeda bedakannya.selalu memberikan motivasi atau semangat kepada peserta didik untuk selalu bersaing sehat dalam diskusi kelompok. Berdasarkan masalah di atas maka penelitian ini dilanjutkan ke siklus II dengan tindakan pemberian reward bagi kelompok yang mampu menampilkan hasil yang lebih baik dalam menjelaskan materi yang didapat. Untuk itu penelitian ini dilanjutkan ke siklus berikutnya.

\section{Siklus II}

\section{Perencanaan}

Pada tahap ini peneliti mempersiapkan perangkat pembelajaran yang terdiri dari RPP, silabus, media pembelajaran, dokumentasi, observasi, dan lembaran tes untuk mendapatkan hasil belajar Bahasa Indonesia peserta didik. Dan menyiapkan reward atau hadiah.

\section{Pelaksanaan}

Pelaksanaan kegiatan belajar mengajar untuk siklus II pertemuan pertama dilaksanakan pada hari Senin di kelas I pada pukul 07.30 sampai dengan 08.35 Wib dengan jumlah peserta didik 21 peserta didik. Dalam hal ini peneliti bertindak sebagai guru. Adapun proses belajar mengajar mengacu pada rencana pelajaran yang telah dipersiapkan. Adapun tema pokok pembelajaran pada siklus dua yaitu Kegiatanku, sedangkan sub tema yang dilakukan kegiatan pagi hari. Siklus II ini terdiri dari tiga kegiatan/tahapan, yaitu pendahuluan, kegiatan inti dan penutup.

Pada kegiatan pendahuluan ini Guru memberikan salam dan mengajak semua peserta didik berdo'a menurut agama dan keyakinan masing-masing. Menyanyikan lagu "Indonesia Raya" bersama-sama. Kemudian peserta didik menyimak penjelasan guru tentang pentingnya sikap disiplin dan tanggung jawab yang akan dikembangkan dalam pembelajaran. Tidak lupa pula guru mengingatkan kepada peserta didik untuk selalu mematuhi protokol kesahatan seperti memakai masker agar terhindar dari virus covid 19. Kemudian kegiatan selanjutnya dilakukan "ice Breaking”, untuk menghidupkan suasana kelas agar semangat (misalnya dengan bernyanyi dan meneriakkan yelyel penyemangat. Selanjutnya guru menjelaskan kegiatan yang akan dilakukan dan tujuan belajar.

Pada kegiatan inti ini guru mengajak peserta didik duduk melingkar, guru meminta peserta didik semuanya menarik nafas dalam-dalam dan menghembuskannya, diulang beberapa kali, lalu peserta didik diminta mendengarkan suara-suara yanga da di sekitar mereka, sambil membayangkan 
bagaimana biasanya suasana di pagi hari. Setelah sekitar 5 menit sebelum peserta didik membuka mata kembali guru bisa menyampaikan motivasi yang dapat mendorong peserta didik untuk bersyukur kepada tuhan atas karunia di pagi hari. Setelah peserta didik membuka mata kembali, guru meminta mereka menjelaskan suasana pagi hari yang mereka bayangkan tadi. Kemudian peserta didik mengamati gambar dan suasana pagi hari yang ditunjukkan oleh guru. Peserta didik diminta mengajukan pertanyaan terkait gambar yang mereka amati. Kemudian guru mengajak peserta didik mendiskusikan kegiatan-kegiatan di pagi hari baik di rumah maupun di sekolah. Peserta didik diminta menyebutkan kata-kata yang berhubungan dengan pagi hari, guru menuliskan kata-kata yang berhubungan dengan pagi hari, lalu guru menuliskan kata-kata yang disebutkan peserta didik di papan tulis agar dapat dibaca oleh peserta didik lain nya setelah tidak ada lagi peserta didik yang menyebutkan, guru dapat menambahkan kosa kata nya jika diperlukan dengan cara memberikan pertanyaan yang memancing ingatan peserta didik. Selanjutnya guru memperkuat pemahaman tentang kosa kata yang dipelajari, kemudian guru melakukan permainan menyusun kartu huruf menjadi kata.

Pada kegiatan penutup ini peserta didik bersama guru melakukan refleksi atas pembelajaran yang telah berlangsung. Setelah itu peserta didik diminta menyelesaikan lembar kerja tentang pengenalan kosa kata yang berhubungan dengan kegiatan pagi hari. Kepada peserta didik yang masih menemui kesulitan, guru melakukan asistensi dan pengarahan. Slanjutnya guru melanjutkan diskusi yang berkaitan dengan kegiatan pagi hari di sekolah, salah satu rutinitas di sekolah di pagi hari yaitu upacara bendara dan diiringi lagu Indonesia Raya. Setelah itu guru mengajak peserta didik mencermati apa saja kegiatan pagi hari di rumah lewat lagu "Bangun Tidur". Setelah itu pembelajaran ditutup dengan do'a yang dipimpin oleh salah satu peserta didik.

Pelaksanaan kegiatan belajar mengajar untuk siklus II pertemuan kedua dilaksanakan pada hari Kamis tanggal 11 Maret 2021 di Kelas I pada pukul 07.30 sampai dengan 08.40 Wib dengan jumlah peserta didik 21 peserta didik. Dalam hal ini peneliti bertindak sebagai guru. Adapun proses belajar mengajar mengacu pada rencana pelajaran yang telah dipersiapkan. Adapun tema yang dibahas pada pertemuan kedua ini adalah tentang keluargaku dan sub tema yang dibahas adalah Anggota Keluargaku. Siklus II ini terdiri dari tiga kegiatan/tahapan, yaitu pendahuluan, kegiatan inti dan penutup.

Pada kegiatan pendahuluan ini Guru memberikan salam dan mengajak semua peserta didik berdo'a menurut agama dan keyakinan masing-masing. Menyanyikan lagu "Indonesia Raya" bersama-sama. Kemudian peserta didik menyimak penjelasan guru tentang pentingnya sikap disiplin dan tanggung jawab yang akan dikembangkan dalam pembelajaran. Tidak lupa pula guru mengingatkan kepada peserta didik untuk selalu mematuhi protokol kesahatan seperti memakai masker agar terhindar dari virus covid 19. Kemudian kegiatan selanjutnya dilakukan "ice Breaking”, untuk menghidupkan suasana kelas agar semangat (misalnya dengan bernyanyi dan meneriakkan yelyel penyemangat. Selanjutnya guru menjelaskan kegiatan yang akan dilakukan dan tujuan belajar. 
Pada kegiatan inti ini dengan bimbingan guru, peserta didik bersama-sama membaca teks keluarga udin. Peserta didik difasilitasi bertanya jawab tentang teks keluarga udin. Peserta didik difasilitasi bertanya jawab tentang teks keluarga udin. Peserta didik menyimak penjelasan guru tentang sikap bersyukur atas karunia tuhan yang maha esa berupa keluarga bahagia. Kemudian peserta didik menyimak penjelasan guru tentang kegiatan-kegiatan menyanyikan lagu satu-satu aku saying Ibu dengan memperhatikan suara tinggi atau rendah. Kemudian guru menunjukkan foto keluarganya.

Pada kegiatan penutup ini peserta didik berpasangan saling menceritakan kegiatan pembelajaran hari itu. Kemudian peserta didik bersama guru melakukan refleksi mengenai apa saja yang telah dipahami, materi apa yang telah dipahami dan materi yang belum dipahami. Kemudian guru bertanya kepada peserta didik bagaimana perasaan selama pembelajaran berlangsung. Peserta didik menyimak kembali arahan guru akan nilai-nilai saying dalam keluarga. Peserta didik bersama guru menyimpulkan kegiatan pembelajaran termasuk menekan sikap syukur santun dan percaya diri. Kegiatan diakhiri dengan merapikan pakaian, peralatan belajar kebersihan kelas. Kemudian pembelajaran di tutup dengan do'a.

\section{Observasi}

Setelah berakirnya pertemuan kedua siklus II diadakan tes untuk melihat peningkatan hasil belajar Bahasa Indonesia peserta didik melalui metode diskusi. Hasil tes tersebut dapat dilihat pada tabel berikut ini:

Tabel 2. Rekapitulasi Hasil Tes Formatif Pada Siklus II

\begin{tabular}{|c|c|c|}
\hline No & Uraian & Hasil \\
\hline 1 & Jumlah Nilai & 1594 \\
\hline 2 & Rata-rata Nilai & 75.90 \\
\hline 3 & Peserta didik Tuntas & 18 \\
\hline 4 & Peserta didik Tidak Tuntas & 3 \\
\hline 5 & Persentase Peserta didik Tuntas & $86 \%$ \\
\hline 6 & Persentase Peserta didik Tidak Tuntas & $14 \%$ \\
\hline
\end{tabular}

Dari tabel di atas dapat dijelaskan bahwa Pada siklus II ini di peroleh rata - rata hasil belajar peserta didik yaitu 75,90 dengan presentase $86 \%$ atau 18 peserta didik dari 21 peserta didik yang tuntas belajar. Hasil tersebut menunjukkan bahwa pada siklus II secara klasikal sudah baik, karena hanya 3 peserta didik yang memperoleh nilai kurang dari 70 atau hanya sebesar $14 \%$ yang belum tuntas.

\section{Refleksi}

Tahap refleksi siklus II dilaksanakan pada hari Senin tanggal 15 Maret 2021 dengan bertempat di ruangan majelis guru SDN 58/X Teluk Majelis yang dibantu oleh seorang observer yang bernama Saprizal, S.Pd.SD. berdasarkan hasil diskusi didapat bahwa pada siklus II guru sudah memfasilitasi kegiatan diskusi dengan baik dengan cara menyiapkan media dan bahan-bahan referensi 
yang dapat digunakan untuk membantu jalannya diskusi peserta didik. Dilihat dari hasil belajar yang didapat juga terjadi peningkatan yang lebih baik serta dengan adanya tindakan pemberian reward. Untuk itu penelitian ini tidak dilanjutkan ke siklus berikutnya.

\section{Diskusi}

Melalui hasil penelitian ini menunjukkan bahwa Metode Diskusi memiliki dampak positif dalam meningkatkan hasil belajar peserta didik. Hal ini dapat dilihat dari semakin mantapnya pemahaman peserta didik terhadap pembelajaran Bahasa Indonesia. Ketuntasan belajar meningkat dari siklus I 38\%, dan siklus II 86\%. Pada siklus II ketuntasan belajar Bahasa Indonesia peserta didik secara klasikal telah tercapai. Hal ini sesuai dengan pendapat Sudjana (2004) bahwa hasil belajar peserta didik pada hakikatnya adalah perubahan tingkah laku sebagai hasil belajar dalam pengertian yang lebih luas mencakup bidang kognitif, afektif, dan psikomotorik. Untuk lebih jelas dapat dilihat pada diagram berikut ini:

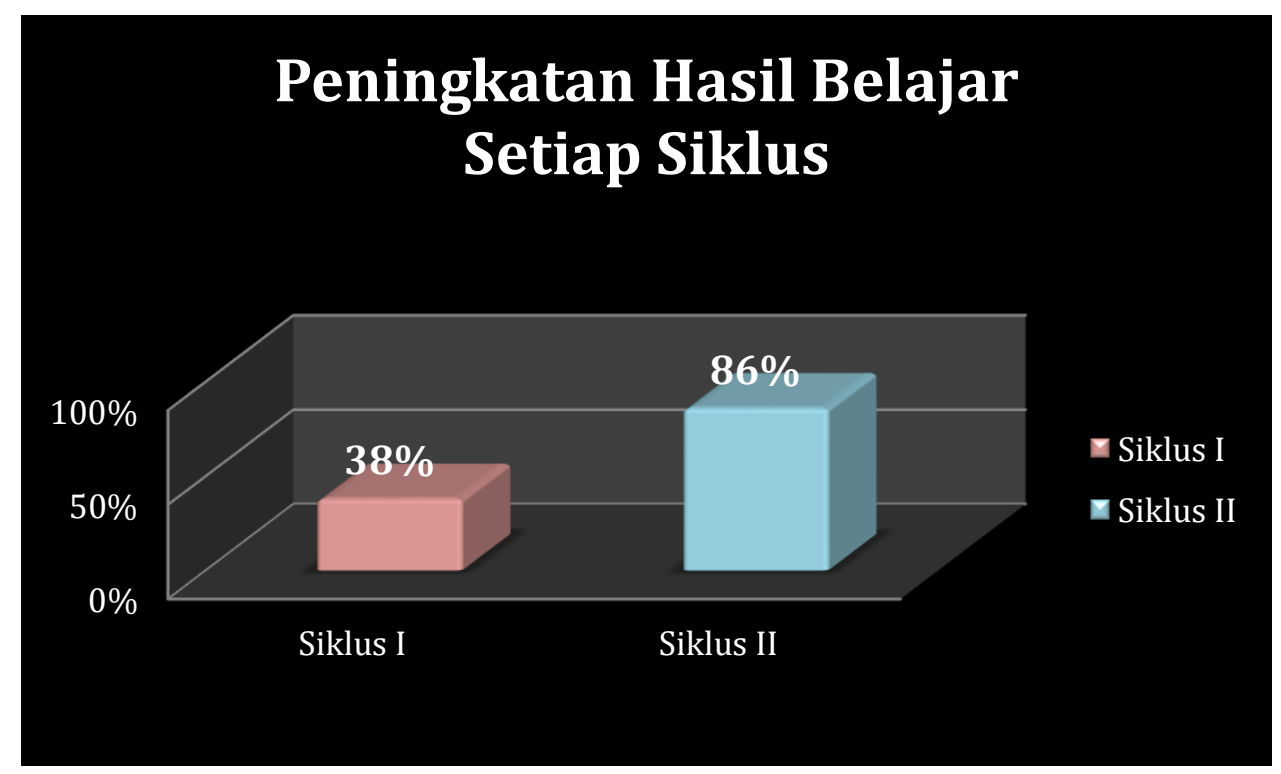

Gambar 1. Grafik Hasil Belajar Bahasa Indonesia Per Siklus

\section{KESIMPULAN}

Dari hasil kegiatan pembelajaran yang telah dilakukan selama dua siklus, dan berdasarkan seluruh pembahasan serta analisis yang telah dilakukan dapat disimpulkan bahwa melalui metode diskusi dapat meningkatkan hasil belajar Bahasa Indonesia peserta didik kelas SDN 58/X Teluk Majelis, yang ditandai dengan siklus I tuntas sebanyak 8 orang (38\%), dan siklus II tuntas sebanyak 18 orang $(86 \%)$ dengan tindakan pemberian reward atau hadiah.

Dari hasil penelitian yang diperoleh dari uraian sebelumnya agar proses belajar pembelajaran Bahasa Indonesia lebih efektif dan lebih memberikan hasil yang optimal bagi peserta didik, maka disarankan yaitu dalam rangka meningkatkan hasil belajar peserta didik, guru hendaknya lebih sering melatih peserta didik dengan berbagai metode pengajaran, walau dalam taraf yang sederhana, dimana peserta didik nantinya dapat menemukan pengetahuan baru, memperoleh konsep dan keterampilan, 
sehingga peserta didik berhasil atau mampu memecahkan masalah-masalah yang dihadapinya. Pada pelaksanaan Metode Diskusi memerlukan persiapan yang cukup matang, sehingga guru harus mampu menentukan atau memilih topik yang benar-benar bisa diterapkan dengan Metode Diskusi dalam proses belajar mengajar sehingga diperoleh hasil yang maksimal. Untuk penelitian yang serupa hendaknya dilakukan perbaikan-perbaikan agar diperoleh hasil yang lebih baik.

\section{REFERENSI}

Agus, Suprijono. 2012. Metode dan Model-Model Mengajar. Bandung : Alfabeta

Anitah W Sri, dkk. 2008. Strategi Pembelajaran di SD. Jakarta: Universitas

Anitah W, Sri, dkk. 2009. Strategi Pembelajaran di SD. Jakarta: Universitas.

Arikunto, Suharsimi. 1992. Prosedur Penelitian Suatu Pendekatan Praktik. Jakarta :Rineka Cipta

Asep Herry Hernawan, dkk. 2008. Modul 10. Pengembangan Kurikulum dan Pembelajaran: Perumusan Tujuan Pembelajaran. Jakarta : Penerbit Universitas.

Bundu, Patta. 2006. Penilaian Keterampilan Proses dan Sikap Ilmiah dalam Pembelajaran Sains di $S D$. Jakarta : Depdiknas

Depdiknas. 2006. Peraturan Menteri Pendidikan Nasional Nomor 22 Tahun 2006 tentang Standar Isi. Jakarta : Depsiknas

Hamalik Oemar. 2012. Manajemen Pengembangan Kurikulum. Bandung: Remaja Rosdakarya

Hamalik, Oemar. 2001. Proses Belajar Mengajar. Jakarta : Bumi Aksara

Pasaribu, I. L. dan Simanjuntak, B. 1983. Pembelajaran Edisi II. Bandung:Tarsito.

Peraturan Pemerintah Nomor 19 Tahun 2005 tentang Standar Nasional Pendidikan UUD 1945 Pasal 31 Ayat 5.

Purwanto. 2008. Metodologi Penelitian Kuantitatif. Yogyakarta: Pustaka Pelajar.

Purwanto. 2010. Evaluasi Hasil belajar. Yogyakarta: Pustaka Pelajar.

Sudjana, Nana. 2002. Penilaian Hasil Proses Belajar Mengajar. Bandung : Remaja Rosdakarya

Sudjana, Nana. 2004. Dasar-dasar Proses Belajar Mengajar. Bandung :Sinar Baru Algensido Offset

Sudjana,Nana. 2002. Dasar-Dasar Proses Belajar Mengajar. Bandung : Sinar Baru Algesindo

Sugihartono, dkk 2007. Psikologi Pendidikan. Yogyakarta : UNY Press

Trianto. 2012. Model-model Pembelajaran Inovatif-Progresif. Jakarta : Kencana. Prenada Media

UU Sisdiknas No. 20 Tahun 2003 Pasal 1 Ayat 1

Warsono dan Hariyanto. 2012. Pembelajaran Aktif. Bandung:Remaja Rosdakarya

Wonorahardjo, Surjani. 2010. Dasar-Dasar Sains Menciptakan Masyarakat Sadar Sains. Jakarta: Indeks

WS. Winkel. 1991. Psikologi Pengajaran. Jakarta : Gramedia. 